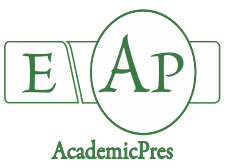

Zhao S and Tang H (2020)

Notulae Botanicae Horti Agrobotanici Cluj-Napoca 48(2):839-848

DOI: $10.15835 /$ nbha48211891

Research Article

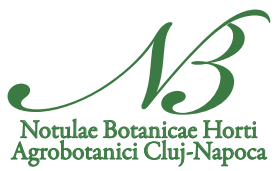

\title{
Enhanced production of valtrate in hairy root cultures of Valeriana jatamansi Jones by methyl jasmonate, jasmonic acid and salicylic acid elicitors
}

\author{
Shuang ZHAO*, Hong TANG \\ Yunnan University of Chinese Medicine, College of Pharmaceutical Sciences, 1076 Yubua Road, Kunming 650500, \\ China; zhaoshuang0871@hotmail.com ("corresponding author)
}

\begin{abstract}
Valtrate is a pharmacologically active epoxyiridoid ester found in the roots and rhizomes of Valeriana jatamansi Jones. The plant produces only small amounts of this metabolite naturally, and so induction of hairy roots as well as elicitation can be useful to increase its commercial production. In this study, strain R1601 of Agrobacterium rhizogenes was used to induce hairy roots in $V$. jatamansi, and stable hairy root cultures of $V$. jatamansi were established successfully. The influence of three exogenous elicitors including methyl jasmonate (MJ), jasmonic acid (JA) and salicylic acid (SA) on valtrate production in the hairy root cultures of $V$.jatamansi was also investigated, and the 25-day-old hairy root cultures were treated with different concentrations of the elicitors at exposure time of 7 days. This present study showed that MJ $(100 \mathrm{mg} / \mathrm{L})$ highly promoted valtrate production at 7 days after elicitation, to a level of 3.63 times higher than that of non-elicited control. SA did not significantly increase the production of valtrate. This is the first-time study to assess the elicitation of hairy root cultures to promote valtrate biosynthesis in $V$.jatamansi and the resulting experiments demonstrated that $\mathrm{MJ}$ was indeed a potent inducer of valtrate biosynthesis.
\end{abstract}

Keywords: hairy root cultures; elicitation; valtrate production; Valeriana jatamansi

\section{Introduction}

Valeriana jatamansi Jones is a famous Traditional Chinese Medicine for gastrointestinal diseases and anxiety indexed in Chinese Pharmacopeia (Part 1) in the 2015 editions, and is widely distributed throughout temperate Himalayan region and southwestern areas of China (He et al., 2018). And it has been employed for treatment of various nervous disorders diseases, as an important substitute for European Valeriana officinalis (Xu et al., 2011). The major active principles of $V$. jatamansi plants are generally held to be a number of epoxyiridoid esters called valepotrates including valtrate, isovaltrate, acevaltrate, didrovaltrate and their homologues (Lin et al., 2010). Phytochemical studies on the plants of the genus Valeriana (Valerianaceae) have resulted in a series of valepotriates, some of which showed potent cytotoxic and antitumor activities (Lin et al., 2013). And valtrate is the major component of valepotrates in $V$. jatamansi plants and has been shown to have 
antifungal, antitumor, antianxiety and cytotoxic activities in many studies (Shi et al., 2014; Tian et al., 2019). Besides valepotrates and other iridoids, sesquiterpenoids and essential oils have also been identified from this species (Bhatt et al., 2012; Li et al., 2013), and all these compounds are accumulated mainly in the roots and rhizomes of $V$. jatamansi plants.

The loss of natural populations requires the development of different genetic manipulation techniques for improving the yields of important phytochemicals. The advantage of producing hairy roots is in their high genetic and biochemical stability, fast growth rates, large-scale secondary metabolite production and possibility for expression of recombinant proteins, regeneration of a whole plant and functional analysis of genes (Petrova et al., 2013; Srivastava et al., 2018). Hairy root cultures of many plant species have already been widely studied regarding the production of secondary metabolites which could be used as pharmaceuticals, cosmetics, and food additives (Thiruvengadam et al., 2014; Huang et al., 2016). In recent years, various bioactive compounds, including ginsenosides (Ha et al., 2016), Artemisinin (Patra et al., 2016), anthraquinones (Perassolo et al., 2017) and benzylisoquinoline alkaloid (Huang et al., 2018) have been produced by hairy root cultures.

Elicitation is a possible aid to overcome various difficulties associated with the large-scale production of most commercially important bioactive secondary metabolites (Halder et al., 2019), and various elicitation strategies have been developed to increase bioactive compound contents from wild and cultivated plants, undifferentiated or differentiated cultures. The exogenous elicitor usually interacts with a plant membrane receptor and activates specific genes, resulting in the stimulation of several bioactive compounds that are synthesized by the plants (Lee et al., 2015). Methyl jasmonate (MJ) and jasmonic acid (JA) are plant-specifific endogenous signaling phytohormones that have long been observed to be potent regulators of elicitor signals for the biosynthesis of plant secondary metabolites (Attaran et al., 2014). Previous genomewide transcript profiling studies revealed that the addition of $\mathrm{MJ}$ or JA induces an extensive transcriptional reprogramming leading to activation of several metabolic pathways including alkaloids (Kang et al., 2004), terpenoids (Misra et al., 2014), phenylpropanoids (Cocetta et al., 2015), lariciresinol (Chen et al., 2015), paclitaxel (Lenka et al., 2015), and podophylloxin (Hazra et al., 2017). Salicylic acid is (SA), as an antioxidant compound and plant growth regulator, is an important signal molecule in the plant defense response against pathogen or viral infections and increase plant tolerance to abiotic stress (Saini et al., 2014). The elicitation of exogenous SA is conducted to enhance the production of pharmacologically active compounds in plant cell cultures or hairy root cultures, such as podophyllotoxin in cell cultures of Linum album (Yousefzadi et al., 2010), D-chiroinositol in cell cultures of buckwheat (Fagopyrum esculentum) (Hu et al., 2011), acteoside in hairy root cultures of Rehmannia glutinosa (Wang et al., 2017), alkaloids and flavonoids in hairy root cultures of Isatis tinctoria (Gai et al., 2019). Hairy root cultures are preferred for the application of elicitation due to their genetic and biosynthetic stability, high growth rate in growth regulator-free media, and production consistence in response to elicitor treatment (Halder et al., 2019). Therefore, it is necessary to optimize the elicitor types and concentrations for the hairy root cultures of $V$. jatamansi.

While there is prolific data published on induction of hairy roots in medicinal plants through gene transfer of Agrobacterium rhizogenes, the data of $V$. jatamansi is quite limited, and there is no published study on elicitor-induced production of secondary metabolites in hairy root cultures of $V$. jatamansi. In the present study, for the first time, the effects of three different elicitors i.e. MJ, JA and SA with different concentrations were investigated on growth rate and valtrate content of the hairy root cultures. This paper suggests the optimal concentrations of elicitors for high level valtrate production in hairy root cultures of $V$. jatamansi. 


\section{Materials and Methods}

\section{Plant material and bacterial strain}

The seeds of $V$. jatamansi were surface-disinfected by dipping them in $70 \%$ (v/v) ethyl alcohol (10 s), and sterilised for 10 minutes with $0.1 \%$ mercury bichloride solution, rinsed with sterile water (5-6 changes) and left for germination on solid MS medium, and maintained at $25^{\circ} \mathrm{C}$ in the light (700 lux).

A. rhizogenes strain R1601 was used in the present study. The bacteria were grown on solid YEB medium containing $5 \mathrm{~g} / \mathrm{L}$ Bacto-beef extract, $1 \mathrm{~g} / \mathrm{L}$ Bacto-yeast extract, $5 \mathrm{~g} / \mathrm{L}$ peptone, $5 \mathrm{~g} / \mathrm{L}$ sucrose, $1.5 \% 0.5 \mathrm{M}$ $\mathrm{MgSO}_{4}$, and subcultured at 1 month intervals. The bacterial suspension was obtained after inoculation of a single colony in $100 \mathrm{~mL}$ conical flasks containing $8 \mathrm{~mL}$ YEB liquid medium. The flasks were placed in a shaker at $220 \mathrm{rpm}$ for $24 \mathrm{~h}$ at $28^{\circ} \mathrm{C}$. The optical density of the bacterial suspension was measured at $600 \mathrm{~nm}$ (OD600) using a spectrophotometer.

\section{Establishment of hairy root cultures}

Young leaves of 5-week-old plantlets were excised from in vitro grown plants and were cut into small segments $(5-10 \mathrm{~mm})$ with a sterile scalpel. Infection of plant material was accomplished by immersion in overnight bacterial (A. rhizogenes strains R1601) suspension for $20 \mathrm{~min}$. All infected leaves were transferred onto MS solid medium without hormones. The co-cultivation continued from 2 to 5 days at $25^{\circ} \mathrm{C}$ in the dark. The uninfected leaves used as control were cultured in the same conditions. After co-culture time the explants were washed three times with sterile distilled water and blotted dry on sterile filter paper. The infected and the uninfected leaves were transferred to hormone-free MS medium, containing $300 \mathrm{mg} / \mathrm{L}$ cefotaxime (Sigma USA) to remove the bacteria.

Approximately 3 weeks after infection, hairy roots which appeared at the infection sites were transferred on solid MS/2 medium containing $300 \mathrm{mg} / \mathrm{L}$ cefotaxime (Sigma, USA). Sterile hairy roots were cultured on solid MS/2 medium and subcultured every 5 weeks. All cultures were maintained in darkness at $25^{\circ} \mathrm{C}$ on a gyratory shaker at $100 \mathrm{rpm}$. All media were hormone-free and adjusted at pH 5.9 before autoclaving.

\section{$D N A$ analysis}

DNA was isolated from hairy roots and from control roots frozen in liquid nitrogen by the MiniBEST Plant Genomic DNA Extraction Kit (TaKaRa, Dalian, China) and quantified by NanoDrop 2000C spectrophotometer (Thermoscientific, USA).

The Ri plasmid of $A$. rbizogenes strains $\mathrm{R} 1601$ was used as a positive control. The primer sequences to amplify a 652-bp portion of the rolB gene (ACCESSION: AB006689.1) were 5'ACTATAGCAAACCCCTCCTGC-3' (forward primer) and 5'-TTCAGGTTTACTGCAGCAGGC- 3' (reverse primer). The primers (5'-ATGCCCGATCGAGCTCAAGT-3' and 5'-AAGTGAAATCTCTG CCATC- $3^{\prime}$ as forward and reverse primers, respectively) specific to the virD2 gene (516-bp, ACCESSION: JQ429317) present in the non-transferred virulence region of the $A$. rhizogenes Ri plasmid were also used in PCR analysis to ensure transformed root tissue was free of bacterial cells.

The PCR reaction consisted of $50 \mathrm{ng}$ of genomic DNA, $0.2 \mathrm{mM}$ of dNTPs, $1.0 \mathrm{U}$ of Taq DNA polymerase, $1.0 \mu \mathrm{M}$ of each primer, and $2.5 \mu \mathrm{L}$ of $10 \times \mathrm{Taq} \mathrm{DNA}$ polymerase buffer in a total of $25 \mu \mathrm{L}$ reaction. The PCR was initiated in Programmable thermal cycler (Bio-Rad S1000, USA) programmed with a hot start at $94^{\circ} \mathrm{C}$ for $4 \mathrm{~min}$, followed by 30 cycles of $94^{\circ} \mathrm{C}$ for $50 \mathrm{~s}, 58^{\circ} \mathrm{C}$ for $45 \mathrm{~s}, 72^{\circ} \mathrm{C}$ for $5 \mathrm{~min}$. The reaction products were analyzed by electrophoresis on a $1.0 \%(\mathrm{w} / \mathrm{v})$ agarose gel and visualized by staining with ethidium bromide. 


\section{Screening of elicitors}

MJ and JA were dissolved in 95\% ethanol and filter sterilized. Stock solution of SA was prepared by dissolving them in distilled water and adjusting the $\mathrm{pH}$ to 5.8. Elicitation studies were carried out with $\mathrm{MJ}$ $(50,100,200 \mathrm{mg} / \mathrm{L})$, JA $(50,100,200 \mathrm{mg} / \mathrm{L})$ and SA $(50,100,200 \mathrm{mg} / \mathrm{L})$. For elicitation, 25 -day-old hairy root cultures were transferred to $100 \mathrm{~mL}$ of fresh medium and supplemented with desired concentrations of elicitors respectively. The same amount of ethanol or water was added to the control cultures. Control and elicited hairy roots were harvested on the $32^{\text {th }}$ day of cultivation and analyzed for Fresh weight (FW), Dry weight (DW) and valtrate content. All the treatments were replicated three times.

\section{Valtrate quantification}

For valtrate extraction, hairy roots were freeze dried, ground and kept in a freezer. DW was determined for each sample after freeze drying. The powdered plant material was extracted five times at $25{ }^{\circ} \mathrm{C}$ with methylene chloride using 30 min sonication.

All samples were filtered through a $0.22 \mu \mathrm{m}$ micro-filter (Merck, Germany) and this solution was used for chemical analysis. High-performance liquid chromatography (HPLC) analysis was carried out using Waters Alliance 2690/2695 LC system with waters 2996 PDA detector. The chromatographic conditions were as follows: C18 column ( $4 \mu \mathrm{m}, 3.9 \times 150 \mathrm{~mm}$ i.d. ) (Waters Nova-Pack) adapted to a guard column $\mathrm{C} 18(3.9 \times 20 \mathrm{~mm})$ (Waters Nova-Pack); mobile phase was isocratic $\mathrm{CH}_{3} \mathrm{CN} / \mathrm{H}_{2} \mathrm{O}, 50: 50(\mathrm{v} / \mathrm{v})$ and flow rate was $1 \mathrm{~mL} / \mathrm{min}$; detector sensitivity set at 1.0 and detection wavelength at $254 \mathrm{~nm}$. Standards valtrate was from Apin Chemicals Ltd. (Abingdon, Oxon, OX14 4RU, UK). the valepotriates were dissolved in methanol, diluted stepwise $(1.0,0.5,0.25,0.125$ and $0.0625 \mathrm{mg} / \mathrm{mL}$ ) and the injection volume was $10 \mu \mathrm{L}$. All analyses were repeated three times employing three replicates each. The metabolite contents were calculated as $\mathrm{mg}$ of the compound per gram of hairy roots DW.

\section{Statistical analysis}

All data analyses were performed using the Statistical Analysis System (SAS 9.4) programme package, and One-way ANOVA was applied in statistical analysis. The means were compared using Fisher's least significant difference (FLSD) test at the $5 \%$ probability level. Data were reported as means \pm standard error (SE).

\section{Results and Discussion}

\section{Establishment of hairy root cultures}

Leaf explants obtained from 5-week-old in vitro grown seedlings of $V$. jatamansi were cut into small segments $(5-10 \mathrm{~mm})$ and were dipped in the suspension of A. rhizogenes R1601 strain (0.6 OD600) for $20 \mathrm{~min}$, and co-cultivated in MS medium containing acetosyringone $(100 \mu \mathrm{M})$ for 2 days was found to be the optimal regime to obtain maximum percentage of hairy root induction. After 2 days, the explants were rinsed with sterile distilled water and placed on solid hormone-free MS medium containing $300 \mathrm{mg} / \mathrm{L}$ cefotaxime. High concentrations of antibiotic ( 400 or $500 \mathrm{mg} / \mathrm{L}$ ) eliminated bacterial contamination and caused darkening and necrosis of plant tissues. And a transformation frequency of $47.6 \%$ was achieved in the present study.

Hairy roots of $V$. jatamansi were formed on the cut surface of the leaf explants after 20-30 days of cocultivation with $A$. rhizogenes R1601, and were developed mainly on the base of the leaf near the petiole and rarely at the leaf tip (Figure 1A). The hairy roots that were formed after inducing an infection with $A$. rhizogenes had a typical hairy roots phenotype, plagiotropism, rapid growth, many lateral branches, and were easily grown in a hormone-free MS medium (Figure 1B). 


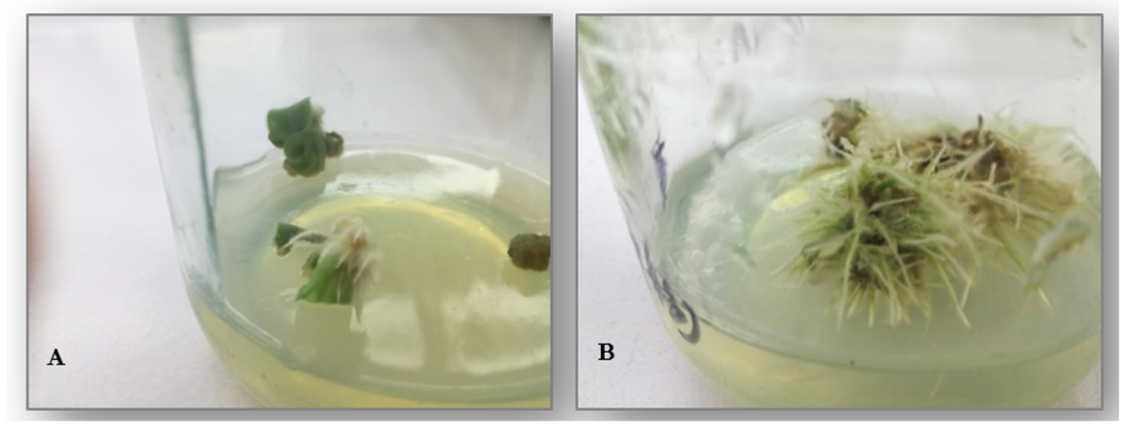

Figure 2. Hairy root induction in $V$. jatamansi through inoculation with $A$. rhizogenes strain R1601. A) profuse hairy roots induced from leaf segments on solidified MS medium, 4 weeks after inoculation. B) a typical hairy root phenotype characterized by fast growth, high lateral branching and lack of geotropism at 1 month of culture of the root segment in the dark after elimination of bacteria

For molecular confirmation of the transgenic nature of hairy roots, the presence of the rol genes (rolA, rolB,$r o l C$ ) located on the T-DNA as the main determinants of hairy root development were examined by PCR analysis using corresponding gene-specific primer pairs. The presence of the $652 \mathrm{bp}$ rolB gene amplified product in the hairy root samples was showed by PCR analysis confirming the transgenic nature of the roots (Figure 2A). The rolB gene is absolutely essential for the induction of hairy roots (Nilsson et al., 1997). To diagnosing the presence of any remaining agrobacteria in the roots; the virD2 gene, located outside the T-DNA, is amplified by PCR. Non-PCR amplification for the virD2 gene demonstrated that there was no bacterial contamination of the hairy root tissues (Figure 2B).

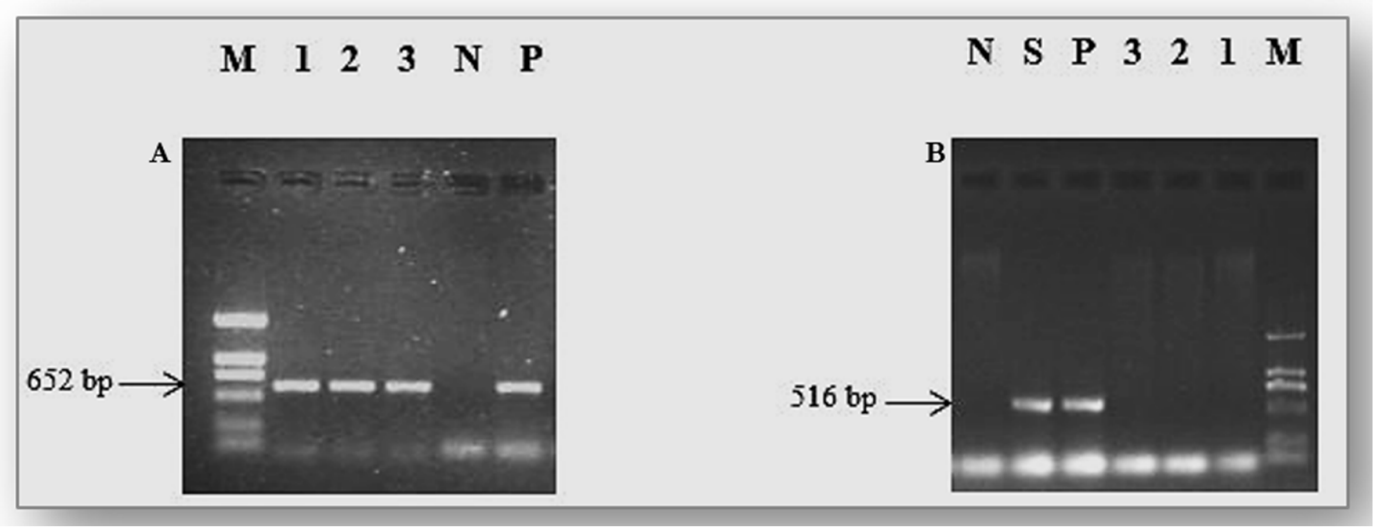

Figure 2. PCR analysis for hairy roots of $V$. jatamansi using the rolB gene (A) and virD2 gene (B) specific primers. M- DL2000 DNA Ladder, N-Untransformed normal root as a negative control, P-the plasmid from $A$. rhizogenes strain 1601 as a positive control, 1, 2 and 3-Transgenic hairy root lines raised from leaf explants, S- A. rhizogenes strain 1601 as second positive control (B)

\section{Effects of elicitors on biomass production of hairy roots}

According to many previous studies, the addition of elicitors at the late exponential growth phase could increase the valtrate content without significantly affecting the biomass so as to enhance the overall productivity (Cui et al., 2012). In the present study, to enhance overall productivity and limit negative effects of elicitors (especially MJ and JA) on growth of roots, elicitation in hairy roots of $V$. jatamansi were tested when the roots were in the late linear or early stationary growth phase $\left(25^{\text {rd }}\right.$ day of the culture period). 
As a result of the transformation with $A$. rhizogenes and hairy root production, 25-day-old hairy root cultures were treated with various elicitors such as MJ, JA and SA, and harvested at day 32 in our hairy root culture system. The FW, DW and valtrate content of the hairy root harvested at day 32 were analysed (Table 1), and all the elicitors were shown to influence the growth of hairy roots in a dose-dependent.

Table 1. Effect of different elicitors on FW, DW and valtrate accumulation

\begin{tabular}{|c|c|c|c|}
\hline Elicitor & FW $(\mathrm{g})$ & DW $(\mathrm{mg})$ & Valtrate $(\mathrm{mg} / \mathrm{g}$ DW $)$ \\
\hline Control & $8.54 \pm 0.003$ & $812 \pm 14$ & $3.18 \pm 0.02$ \\
\hline $\mathrm{MJ}-50 \mathrm{mg} / \mathrm{L}$ & $9.10 \pm 0.12$ & $895 \pm 21$ & $5.76 \pm 0.08$ \\
\hline $\mathrm{MJ}-100 \mathrm{mg} / \mathrm{L}$ & $10.86 \pm 0.13$ & $993 \pm 8$ & $11.57 \pm 0.25$ \\
\hline $\mathrm{MJ}-200 \mathrm{mg} / \mathrm{L}$ & $9.77 \pm 0.03$ & $921 \pm 14$ & $10.11 \pm 0.09$ \\
\hline $\mathrm{JA}-50 \mathrm{mg} / \mathrm{L}$ & $8.76 \pm 0.16$ & $824 \pm 10$ & $4.38 \pm 0.03$ \\
\hline $\mathrm{JA}-100 \mathrm{mg} / \mathrm{L}$ & $9.92 \pm 0.11$ & $953 \pm 5$ & $8.63 \pm 0.07$ \\
\hline $\mathrm{JA}-200 \mathrm{mg} / \mathrm{L}$ & $9.47 \pm 0.17$ & $906 \pm 9$ & $7.92 \pm 0.17$ \\
\hline $\mathrm{SA}-50 \mathrm{mg} / \mathrm{L}$ & $7.24 \pm 0.10$ & $685 \pm 21$ & $2.99 \pm 0.05$ \\
\hline $\mathrm{SA}-100 \mathrm{mg} / \mathrm{L}$ & $7.89 \pm 0.23$ & $721 \pm 7$ & $3.07 \pm 0.15$ \\
\hline $\mathrm{SA}-200 \mathrm{mg} / \mathrm{L}$ & $6.83 \pm 0.19$ & $653 \pm 18$ & $2.64 \pm 0.12$ \\
\hline
\end{tabular}

Each value represents the mean \pm SE of three samples

MJ treatment caused a slight decline in biomass throughout the exposure period and maximum inhibition of growth was found after 7 th days of exposure time at $200 \mathrm{mg} / \mathrm{L} \mathrm{MJ}$ (Table 1), and also JA treatment caused maximum inhibition of growth was found after 7 th days of exposure time at $200 \mathrm{mg} / \mathrm{L} \mathrm{JA}$. This negative effect may be due to a direct toxic effect of MJ or JA and loss of viability of the culture (Kuzma et al., 2009; Hu et al., 2011).

SA did not affect the growth rate at exposure time of 7 days, and both FW and DW of elicited roots at the end of the culture period was similar to the control (Table 1). This is in accordance with previous studies reporting that SA treatment has no significant negative effects on growth of hairy root cultures of $V$. officinalis (Torkamani et al., 2014).

\section{Effects of elicitors on valtrate production of hairy roots}

It is known that secondary metabolites increase through MJ elicitation, but to reach the highest level the time required is different for each biosynthetic pathway and even each compound type. The addition of MJ or JA led to significant increases of valtrate contents at all concentrations as compared to control cultures (Table 1; Figure 3). Maximum increase in valtrate accumulation was obtained with the addition of $100 \mathrm{mg} / \mathrm{L} \mathrm{MJ}$ $(11.57 \mathrm{mg} / \mathrm{g} ; 3.63$ times higher than control of $3.18 \mathrm{mg} / \mathrm{g})$. As for JA treatment, the highest increase in valtrate content $(8.63 \mathrm{mg} / \mathrm{g})$ was obtained with the concentration of $100 \mathrm{mg} / \mathrm{L}$.

MJ has been accepted as a signal transduction elicitor for plant defence responses, and reported that MJ significantly increases the release of resveratrol in the hairy root cultures of muscadine grape (Nopo-Olazabal et al., 2014). And MJ is also considered to be effective elicitors that can increase the accumulation of tanshinone (Shi et al., 2016; Wei et al., 2019). And glucosinolate levels are increased in hairy root cultures of Sinapis alba and Brassica rapa in response to JA, but root growth was inhibited (Kastell et al., 2013). The co-treatment with methyl jasmonate and methyl- $\beta$-cyclodextrin has been the most effective in providing sustainable and high levels of stilbenoids in grapevine (Vitis vinifera), muscadine (Vitis. rotundifolia), and peanut (Arachis hypogaea) hairy root cultures (Malik, 2017). But the production of dominant xanthone was not significantly affected by both MJ or JA in the hairy root cultures of Gentiana dinarica (Dijana et al., 2017).

In this study, SA failed to increase the valtrate content as compared to the control (Table 1; Figure 3). The inefficiency of SA in promoting valtrate production in adventitious roots of $V$. amurensis has also been reported (Cui et al., 2012). And the production of dominant xanthone was not significantly affected by both 
SA in the hairy root cultures of Gentiana dinarica (Dijana et al., 2017). However, several studies have shown the effectiveness of SA in improving target metabolites in the plant cells (Yousefzadi et al., 2010; Hu et al., 2011).

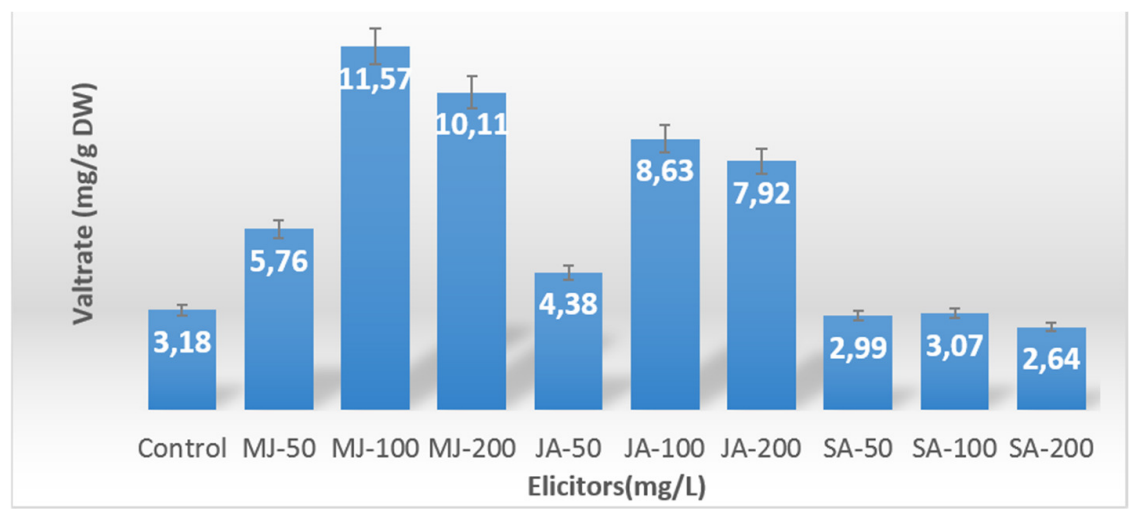

Figure 3. Effect of various concentrations of MJ, JA and SA on valtrate of $V$. jatamansi hairy root cultures for 7 days. Error bars represent the standard error of the mean of three repeated experiments

\section{Conclusions}

In recent years, $A$. rhizogenes-mediated hairy root cultures have offered opportunities for stable production of a wide range of plant secondary metabolites compared to undifferentiated plant cell/callus cultures, and turned this system as an attractive tool for industrial processes. Plant hairy root cultures via the implementation of effective elicitation strategies can offer attractive biotechnological platforms for the enhanced production of phytochemicals of pharmaceutical interest, and various elicitation strategies have been developed to increase bioactive compound contents in many hairy root cultures. However, elicitation is a highly complex process and depends on many factors such as elicitor types and concentrations, plant species, growth stage of hairy root cultures, the time at which the elicitor is added and contact time with the elicitor. These parameters need to be optimized according to the plant species and types of bioactive compound. For the first time, the elicitation of exogenous signal molecules was conducted to enhance the production of pharmacologically active valtrate in $V$.jatamansi hairy root cultures. This present study established stable hairy root lines of $V$. jatamansi successfully, and optimized different concentrations of the three different elicitors i.e. MJ, JA and SA on growth rate and valtrate content of the hairy root cultures. The results obtained in this study demonstrated that $\mathrm{MJ}$ at $100 \mathrm{mg} / \mathrm{L}$ significantly enhanced the biosynthesis of valtrate from hairy root cultures, and the valtrate content obtained with the addition of $100 \mathrm{mg} / \mathrm{L} \mathrm{MJ}$ was 3.63 times higher than the control. Furthermore, SA does not appear to be an effective elicitor to increase valtrate content in this study. These results indeed show that varying elicitors have diverse inducing effects according to the plant species and types of bioactive compound. This work may help further investigate the optimal concentrations and exposure times of MJ for the possible large-scale production of valtrate from hairy root cultures of $V$. jatamansi in a bioreactor system. However, further research is required to explore the efficacy of $V$. jatamansi hairy roots as a source of valuable secondary metabolites. 


\section{Authors' Contributions}

ZS performed the experiments and wrote the manuscript, TH collected the materials compiled the data. All authors read and approved the final manuscript.

\section{Acknowledgements}

This research was financially supported by the Application and Basis Research Program of Yunnan Province-Chinese Medicine Joint Project China [No. 2017FF116(-008)].

\section{Conflict of Interests}

The authors declare that there are no conflicts of interest related to this article.

\section{References}

Attaran E, Major IT, Cruz JA, Rosa BA, Koo AJ, Chen J, ... Howe GA (2014). Temporal dynamics of growth and photosynthesis suppression in response to jasmonate signaling. Plant Physiology 165:1302-1314. https://doi.org/10.1104/pp.114.239004

Bhatt ID, Dauthal P, Rawat S, Gaira KS, Jugran A, Rawal RS, Dhar U (2012). Characterization of essential oil composition, phenolic content, and antioxidant properties in wild and planted individuals of Valeriana jatamansi Jones. Scientia Horticulturae 136:61-68. https://doi.org/10.1016/j.scienta.2011.12.032

Chen R, Li Q, Tan H, Chen J, Xiao Y, Ma R, ... Zhang L (2015). Gene-to-metabolite network for biosynthesis of lignans in MeJA-elicited Isatis indigotica hairy root cultures. Frontiers in Plant Science 6:952-960. https://doi.org/ $10.3389 / \mathrm{fpls.2015.00952}$

Cocetta G, Rossoni M, Gardana C, Mignani I, Ferrante A, and Spinardi A (2015). Methyl jasmonate affects phenolic metabolism and gene expression in blueberry (Vaccinium corymbosum). Physiologia Plantarum 153:269-283. https://doi.org/10.1111/ppl.12243

Cui L, Wang Z, Zhou X (2012). Optimization of elicitors and precursors to enhance valtrate production in adventitious roots of Valeriana amurensis Smir. ex Kom. Plant Cell, Tissue and Organ Culture 108(3):411-420. https://doi.org/10.1007/s11240-011-0052-2

Dijana KM, Jankovic T, Uzelac B, Vinterhalter D, Vinterhalter B (2017). Effect of elicitors on xanthone accumulation and biomass production in hairy root cultures of Gentiana dinarica. Plant Cell, Tissue and Organ Culture 130(5): 1-10. https://doi.org/10.1007/s11240-017-1252-1

Gai Q, Jiao J, Wang X, Zang Y, Niu L, Fu Y (2019). Elicitation of Isatis tinctoria L. hairy root cultures by salicylic acid and methyl jasmonate for the enhanced production of pharmacologically active alkaloids and flavonoids. Plant Cell, Tissue and Organ Culture 137:77-86. https://doi.org/10.1007/s11240-018-01553-8

Ha L, Pawlicki-Jullian N, Pillon-Lequart M, Boitel-Conti M, Duong H, Gontier E (2016). Hairy root cultures of Panax vietnamensis, a promising approach for the production of ocotillol-type ginsenosides. Plant Cell, Tissue and Organ Culture 126(1): 93-103. https://doi.org/10.1007/s11240-016-0980-y

Hazra S, Bhattacharyya D, Chattopadhyay S (2017). Methyl jasmonate regulates podophyllotoxin accumulation in Podophyllum hexandrum by altering the ROS-responsive podophyllotoxin pathway gene expression additionally through the down regulation of few interfering miRNAs. Frontiers in Plant Science 8:164-171. https://doi.org/10.3389/fpls.2017.00164 
He X, Wang S, Shi J, Sun Z, Lei Z, Yin Z, ... Xie H (2018) Genotypic and environmental effects on the volatile chemotype of Valeriana jatamansi Jones. Frontiers in Plant Science 9: 1003-1012. https://doi.org/ 10.3389/fpls.2018.01003

Hu Y, Yu Y, Piao C, Liu J, Yu H (2011). Methyl jasmonate- and salicylic acid-induced D-chiro-inositol production in suspension cultures of buckwheat (Fagopyrum esculentum), Plant Cell, Tissue and Organ Culture 106:419-424. https://doi.org/10.1007/s11240-011-9938-2

Huang X, Yao J, Zhao Y, Xie D, Jiang X, Xu Z (2016). Efficient rutin and quercetin biosynthesis through flavonoidsrelated gene expression in Fagopyrum tataricum gaertn. hairy root cultures with UV-B irradiation. Frontiers in Plant Science 7: 63-74. https://doi.org/10.3389/fpls.2016.00063

Halder M, Sarkar S, Jha S (2019). Elicitation: A biotechnological tool for enhanced production of secondary metabolites in hairy root cultures. Engineering in Life Sciences 19(12):58-71. https:// doi.org/10.1002/elsc.201900058

Huang P, Xia L, Liu W, Jiang R, Liu X, Tang Q, ... Zeng J (2018). Hairy root induction and benzylisoquinoline alkaloid production in Macleaya cordata. Scientific Reports 8(1):11986-11995. https://doi.org/10.1038/ s41598-01830560-0

Kang SM, Jung HY, Kang YM, Yun DJ, Bahk JD, Yang JK, ... Choi MS (2004). Effects of methyl jasmonate and salicylic acid on the production of tropane alkaloids and the expression of PMT and $\mathrm{H} 6 \mathrm{H}$ in adventitious root cultures of Scopolia parviflora. Plant Science 166:745-751. https://doi: 10.1016/j.plantsci.2003.11.022

Kastell A, Smetanska I, Ulrichs C, Cai Z, Mewis I (2013). Effects of phytohormones and jasmonic acid on glucosinolate content in hairy root cultures of Sinapis alba and Brassica rapa. Applied Biochemistry and Biotechnology 169(2):624-635. https://doi.org/10.1007/s12010-012-0017-x

Kuzma L, Bruchajzer E, Wysokinska H (2009). Methyl jasmonate effect diterpenoid accumulation in Salvia sclarea hairy root culture in shake flasks and sprinkle bioreactor. Enzyme and Microbial Technology 44:406-410. Https://doi.org/10.1016/j. enzmictec. 2009.01.005

Lee EJ, Park SY, Paek KY (2015). Enhancement strategies of bioactive compound production in adventitious root cultures of Eleutherococcus koreanum Nakai subjected to methyl jasmonate and salicylic acid elicitation through airlift bioreactors. Plant Cell, Tissue and Organ Culture 120(1):1-10. https://doi.org/10.1007/s11240-014-0567-4

Lenka SK, Nims NE, Vongpaseuth K, Boshar RA, Roberts SC, Walker E (2015). Jasmonate-responsive expression of paclitaxel biosynthesis genes in Taxus cuspidata cultured cells is negatively regulated by the bHLH transcription factors TcJAMYC1, TcJAMYC2, and TcJAMYC4. Frontiers in Plant Science 6:115-122. https://doi.org/10.3389/fpls.2015.00115

Li YD, Wu ZY, Li HM, Li HZ, Li RT (2013). Iridoids from the roots of Valeriana jatamansi. Helvetica Chimica Acta 96:424-430. https://doi.org/10.1002/blca.201100465

Lin S, Chen T, Liu XH, Shen YH, Li HL, Shan L,... Wang H (2010). Iridoids and lignans from Valeriana jatamansi. Journal of Natural Products 73(4):632-638. https://doi.org/10.1021/np900795c

Lin S, Zhang ZX, Chen T, Ye J, Dai WX, Shan L, ... Zhang WD (2013). Characterization of chlorinated valepotriates from Valeriana jatamansi. Phytochemistry (Amsterdam) 85:185-193. https://doi.org/10.1016/ j.phytochem.2012.08.015

Malik S (2017). Production of plant derived natural compounds through hairy root culture. Springer, Cham. https://doi.org/10.1007/978-3-319-69769-7

Misra RC, Maiti P, Chanotiya CS, Shanker K, Ghosh S (2014). Methyl jasmonate-elicited transcriptional responses and pentacyclic triterpene biosynthesis in sweet basil. Plant Physiology 164:1028-1044. https://doi.org/ 10.1104/pp.113.232884

Nilsson O, Olsson O (1997). The role of the Agrobacterium rhizogenes rol genes in the formation of hairy roots, Physiologia Plantarum 100:463-473.

Nopo-Olazabal C, Condori J, Nopo-Olazabal L, Medina-Bolivar F (2014). Differential induction of antioxidant stilbenoids in hairy roots of Vitis rotundifolia treated with methyl jasmonate and hydrogen peroxide. Plant Physiology and Biochemistry 74:50-69. https://doi.org/10.1016/j.plaphy.2013.10.035

Patra N, Srivastava AK (2016). Artemisinin production by plant hairy root cultures in gas-and liquid-phase bioreactors. Plant cell reports 35:143-153. https://doi.org/10.1007/s00299-015-1875-9 
Perassolo M, Cardillo A, Mugas ML, Núñez Montoya S, Giulietti A, Rodríguez Talou J (2017). Enhancement of anthraquinone production and release by combination of culture medium selection and methyl jasmonate elicitation in hairy root cultures of Rubia tinctorum. Industrial Crops and Products 105:124-132. https://doi.org/10.1016/j.indcrop.2017.05.010

Petrova M, Zayova E, Vlahova M (2013). Induction of hairy roots in Arnica montana L. by Agrobacterium rhizogenes. Central European Journal of Biology 8(5):470-479. https://doi.org/10.2478/s11535-013-0157-6

Saini RK, Prashanth KVH, Shetty NP, Giridhar P (2014). Elicitors, SA and MJ enhance carotenoids and tocopherol biosynthesis and expression of antioxidant related genes in Moringa oleifera Lam leaves. Acta Physiologya Plantarum 36:2695-2704. https://doi.org/10.1007/s11738-014-1640-7

Shi M, Zhou W, Zhang J, Huang S, Wang H, Kai G (2016). Methyl jasmonate induction of tanshinone biosynthesis in Salvia miltiorrhiza hairy roots is mediated by Jasmonate Zim-Domain repressor proteins. Scientific Reports 6:209-219. https://doi.org/10.1038/srep20919

Shi S, Shi J, Liu Y, Wang Y, Wang C, Hou W, Guo J (2014). The anxiolytic effects of valtrate in rats involves changes of corticosterone levels. Evidence-based Complementary and Alternative Medicine 2014(0):325948. https://doi.org/10.1155/2014/325948

Srivastava V, Mehrotra S, Mishra S (2018). Hairy Roots: An effective tool of plant biotechnology. Springer, Singapore. https://doi.org/10.1007/978-981-13-2562-5_13 ISBN978-981-13-2561-8

Tian S, Wang Z, Wu Z, Wei Y, Yang B, Lou S (2019). Valtrate from Valeriana jatamansi Jones induces apoptosis and inhibits migration of human breast cancer cells in vitro. Natural Product Research 1:1-4. https://doi.org/10.1080/14786419.2018.1548454

Thiruvengadam M, Praveen N, Kim E, Kim S, Chung I (2014). Production of anthraquinones, phenolic compounds and biological activities from hairy root cultures of Polygonum multiflflorum Thunb. Protoplasma 251:555-566. https://doi.org/10.1007/s00709-013-0554-3

Torkamani M, Jafari M, Abbaspour N, Heidary R, Safaie N (2014). Enhanced production of valerenic acid in hairy root culture of Valeriana officinalis by elicitation. Central European Journal of Biology 9(9):853-863. https://doi.org/10.2478/s11535-014-0320-3

Wang F, Zhi J, Zhang Z, Wang L, Suo Y, Xie C, ... Sun H (2017). Transcriptome analysis of salicylic acid treatment in Rehmannia glutinosa hairy roots using RNA-seq technique for identification of genes involved in acteoside biosynthesis. Frontiers in Plant Science 8:787. https://doi.org/ 10.3389/fpls.2017.00787

Wei T, Gao Y, Deng K, Zhang L, Chen C (2019). Enhancement of tanshinone production in Salvia miltiorrhiza hairy root cultures by metabolic engineering. Plant Methods 15(53):1-11. https://doi.org/10.1186/s13007-019-04393

Xu J, Yang B, Guo Y, Jin DQ, Guo P, Liu C, ... Sun Z (2011). Neuroprotective bakkenolides from the roots of Valeriana jatamansi. Fitoterapia 82(6):849-853. https://doi.org/10.1016/j.fitote.2011.04.012

Yousefzadi M, Sharifi M, Behmanesh M, Ghasempour A, Moyano E, Palazon J (2010). Salicylic acid improves podophyllotoxin production in cell cultures of Linum album by increasing the expression of genes related with its biosynthesis. Biotechnology Letters 32:1739-1743. https://doi.org/10.1007/s10529-010-0343-4

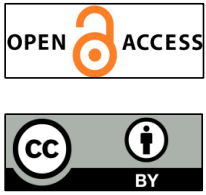

The journal offers free, immediate, and unrestricted access to peer-reviewed research and scholarly work. Users are allowed to read, download, copy, distribute, print, search, or link to the full texts of the articles, or use them for any other lawful purpose, without asking prior permission from the publisher or the author.

License - Articles published in Notulae Botanicae Horti Agrobotanici Cluj-Napoca are Open-Access, distributed under the terms and conditions of the Creative Commons Attribution (CC BY 4.0) License. (c) Articles by the authors; UASVM, Cluj-Napoca, Romania. The journal allows the author(s) to hold the copyright/to retain publishing rights without restriction. 